\title{
The foraging behavior of the Large-headed Flatbill, Ramphotrigon megacephalum and the Dusky-tailed Flatbill, Ramphotrigon fuscicauda (Aves: Tyrannidae)
}

\author{
Tomaz Nascimento de Melo ${ }^{1, *} \&$ Edson Guilherme ${ }^{2}$
}

\author{
'Programa de Pós-Graduação em Ecologia e Manejo de Recursos Naturais, Universidade Federal do Acre. Rodovia \\ BR 364, km 4, Distrito Industrial, 69915-900 Rio Branco, AC, Brazil. \\ ${ }^{2}$ Laboratório de Ornitologia, Centro de Ciências Biológicas e da Natureza, Universidade Federal do Acre. Rodovia \\ BR 364, km 4, Distrito Industrial, 69915-900 Rio Branco, AC, Brazil. \\ "Corresponding Author: tomazramphotrigon@gmail.com
}

\begin{abstract}
Southwestern Amazonia has great bird diversity which includes birds specialized in bamboo forests. In this region, bamboo is considered a key element of the landscape. The objective of this study was to investigate and describe the foraging behavior of the Large-headed Flatbill, Ramphotrigon megacephalum (Swainson, 1835) and the Dusky-tailed Flatbill, Ramphotrigon fuscicauda Chapman, 1925, which occur sympatrically in the region and are considered bamboo specialists. This study was conducted between November 2013 and September 2014, within two fragments in the eastern portion of the state of Acre: Fazenda Experimental Catuaba, in the municipality of Senador Guiomard; and Reserva Florestal Humaitá, in Porto Acre. A total of 109 and 97 foraging events were registered, for the Large-headed Flatbill and the Dusky-tailed Flatbill, respectively. The two species frequently used bamboos for searching and capturing their prey. However, the large-headed Flatbill was more specialized in bamboo substrates. Both species use similar foraging techniques and the differences found between the two are minor, but when taken together, these differences may explain their ability to co-exist.
\end{abstract}

KEY WORDS. Bamboo, feeding, flycatchers, Guadua, specialization.

Forests dominated by Guadua bamboos cover an area of approximately $161,500 \mathrm{~km}^{2}$ in the southwestern Amazon basin, encompassing the southeast of Peru, north of Bolivia and west of Brazil (Silveira 2005, Carvalho et al. 2013). They represent $38 \%$ of the forest cover in the state of Acre, Brazil (Silveira 2005, GuILHERME \& SANTOS 2009). In that region, at least 19 bird species are classified as bamboo specialists, including the Large-headed Flatbill Ramphotrigon megacephalum (Swainson, 1835) and the Dusky-tailed Flatbill Ramphotrigon fuscicauda Chapman, 1925 classified as near-obligate bamboo specialists (KrATTER 1997).

Abundance of food, associated with the distinct vegetation that covers large areas, are important habitat attributes for Guadua. Despite the costs of specialization by birds in a habitat that is subjected to massive plant death after flowering events (SILVEIRA 2005), species live in Guadua are greatly specialized. The high density of bamboo culms in their habitat influences the way birds forage and the maneuvers they use, besides substrate availability.

Flycatchers forage using stereotyped search and capture techniques. This is characterized by stationary periods followed by attempts to capture prey, or switch to a new perch, and it is classified according to the type of technique used to forage (FITzPATRICK 1981). According to a classification, R. megacephalum and R. fuscicauda are considered pearch-gleaners (FitzPATRIck 1980); however, it is noteworthy that both species capture prey in the air, a characteristic technique of aerial-halkers. A study involving 28 flycatcher species reported that the most used substrates for prey capture are live leaves, and the air (Gabriel \& Pizo 2005).

Even though the foraging behavior of some flycatcher species has already been studied (e.g., FitzPatrick 1980, 1981, Gabriel \& Pizo 2005, Lopes 2005, Delgadillo 2011, Martins-Oliveira et al. 2012), the foraging tactics used by several species are still unknown (Gabriel \& Pizo 2005). Thus, this study aims to investigate and to detail the foraging strategies used by R. megacephalum and $R$. fuscicauda.

\section{MATERIAL AND METHODS}

The present study was conducted in two areas in eastern state of Acre: 1) Reserva Florestal Humaitá (RFH) $\left(09^{\circ} 44^{\prime} 02^{\prime \prime} \mathrm{S}\right.$, $67^{\circ} 41^{\prime} 25^{\prime \prime} \mathrm{W} ; 130$ to 179 masl). It is located in the municipality of 
Porto Acre, and comprises ca. 3,700 ha. The area belongs to the National Institute of Agrarian Reform (INCRA), and was donated to the Federal University of Acre (UFAC) for research purposes. The vegetation of the RFH is characterized by a gradient, with prevalence of open forests with bamboos (Guadua weberbaueri Pilg) in higher areas, and open forests with palm trees in lower areas (BARroso et al. 2011). 2) Fazenda Experimental Catuaba (FEC) $\left(10^{\circ} 04^{\prime} 00^{\prime \prime} \mathrm{S}, 67^{\circ} 37^{\prime} 00^{\prime \prime} \mathrm{W} ; 214\right.$ masl). This ca. 860 ha is located in the municipality of Senador Guiomard and belongs to the INCRA, however it is administered by UFAC (RASMUSSEN et al. 2005). The vegetation is classified as dense terra-firme forest and secondary vegetation in several regeneration stages, including bamboo (Guadua weberbaueri) patches within a surrounding pasture matrix (RASMUSSEN et al. 2005, SiLveira 2005).

The climate in the region, according to Köppen, is Am equatorial, hot and humid, with annual mean temperatures of $24.5^{\circ} \mathrm{C}$ (minimum) and $32^{\circ} \mathrm{C}$ (maximum). The annual rainfall varies between $1,600 \mathrm{~mm}$ and $2,750 \mathrm{~mm}$, with a wetter season from November to April and a drier season from May to September (Schaefer 2013). Data was collected within 54 days (21 days at FEC and 33 days at RFH) in November 2013 and April, May, June, August and September 2014.

Observations were conducted along trails: a $5 \mathrm{~km}$ long trail (Fig. 1) at FEC and two trails at RFH, one $5 \mathrm{~km}$ long and the other $4 \mathrm{~km}$ long. A minimum distance of $500 \mathrm{~m}$ was established to separate individuals and avoid spatial pseudo-replication. The definition of foraging strategies follows REMSEN \& RoBINSON (1990). The following parameters of categorical variables were described and categorized: (1) search behavior, (2) search substrate, (3) attack behavior, (4) attack angle (5) attack substrate, (6) prey size in relation to bird bill and (7) food-handling techniques.

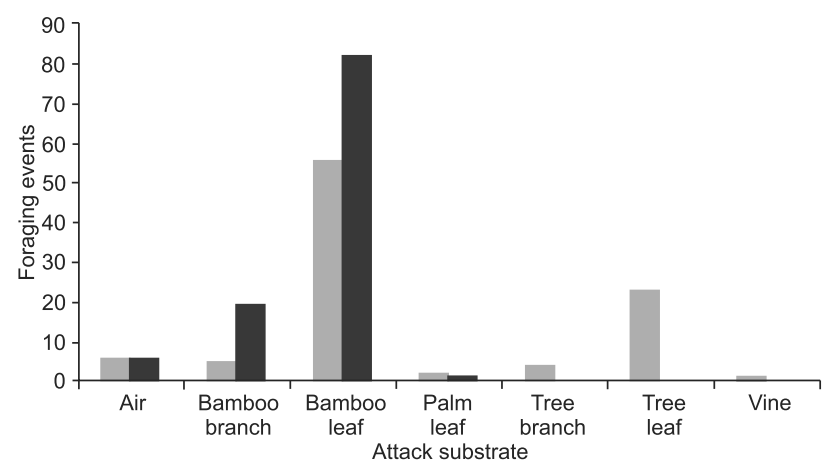

Figure 1. Attack substrates used by the Ramphotrigon fuscicauda (grey) and R. megacephalum (black) to capture the prey $\left(\chi^{2}=41.185\right.$, $\mathrm{df}=7, \mathrm{p}<0.05)$.

The continuous variables observed were: (1) foraging height (m), (2) search time (s), (3) distance covered in the attack (m), (4) number of perches used during the search time and (5) searching time by perch (s). Variables measured in distance were estimated visually and the ones measured in time we estimated using a stopwatch. Additionally, we collected information on the number of registered individuals during foraging, vocalization behavior, and association with mixed flocks. Data was collected from 6:00 to 10:00 a.m. and 2:00 to 6:00 p.m. The location of birds was determined visually, with aid of vocalization. When an individual was identified, observations using a 10x42 mm binocular at a $5 \mathrm{~m}$ minimum distance were taken, aiming to minimize interference on the bird's natural behavior. A greater minimum distance was not possible due to the poor visibility of the forest habitat, dominated by bamboos. Behavioral observations were recorded with a portable digital recorder and were later transcribed to a spreadsheet. When the behavior of an 'individual was initially recorded, the bird was monitored for as long as possible, and its movements during the search for food were registered. Whenever more than one individual were present during the observations, we selected one as the focal-individual, based on how easy it was to see it. Behaviors that ended with attack and prey capture were considered effective foraging events (Martins-Oliveira et al. 2012). For the same individual, foraging behavior records were separated by at least 10 minutes, with the maximum of three foraging events in the same point per day (adapted from Martins-Oliveira et al. 2012).

To check for differences in the continuous variables between both species, the Student's t test was applied, using the software $\mathrm{R}$ version 3.1.1 (R CoRe Team 2014). For categorical variables, the $\chi^{2}$ test (contingency table) was applied, using the software Systat 12.0 (Systat 2008). Tests had significance levels of 0.05 .

\section{RESULTS}

We collected 109 foraging records of R. megacephalum and 97 of $R$. fuscicauda, in 280 hours of observations. During forage, the only search strategy used by both species was stationary, which occurs when the bird remains perched, only moving the head during the search. The behavior of following mixed flocks of insectivore birds was noteworthy in R. megacephalum (14.6\%), but it was infrequent in $R$. fuscicauda (2\%). The presence of two birds during foraging happened in 55\% of the observations on R. megacephalum, in April, May, June and August 2014. Two R. fuscicauda were seen foraging together in $16.4 \%$ of the observations. Both species, in roughly half of the observations, vocalized while foraging (50.5\%).

Relative to the search substrate, both species used basically two types of substrate: horizontal bamboo branches and horizontal branches of trees and bushes. In most of the observations, both species used only bamboo branches during foraging: $R$. megacephalum (95.4\%) and R. fuscicauda (66\%). Alternation in the use of bamboo, tree and bush branches in the same foraging event were infrequently observed: $R$. megacephalum $(4.6 \%)$ and $R$. fuscicauda (7.2\%). The exclusive use of trees and bush branches, without the use of bamboo substrates, during some foraging events was only observed in $R$. fuscicauda $(26.8 \%)\left(\chi^{2}=\right.$ 
35.277, $\mathrm{df}=2, \mathrm{p}<0.05)$. After locating the prey, both species used two types of attack movements. The Sally-strike movement consists of flying from a perch and hitting the prey either on a substrate or in the air, without gliding, hovering or landing. This movement was the most used by $R$. megacephalum $(79.8 \%)$ and $R$. fuscicauda $(80.4 \%)$. The sally-hover move is similar to the sally-strike, but differs from it in that the bird hovers in the air for a few seconds, quickly clapping wings in front of the substrate at the end of the maneuver. This move was used less frequently by $R$. megacephalum (20.2\%) and R. fuscicauda (19.6\%) $\left(\chi^{2}=0.011, \mathrm{df}=1, \mathrm{p}=0.91\right)$.

The direction of the most used attack move was diagonal-up: R. megacephalum (72.4\%) and R. fuscicauda (73.2\%). In sequence, birds used diagonal-down movements: $R$. megacephalum (17.4\%) and $R$. fuscicauda (20.6\%). Horizontal direction of attack movement was less frequently used: $R$. megacephalum $(10 \%)$ and $R$. fuscicauda $(6.2 \%)\left(\chi^{2}=1.228, \mathrm{df}=2, \mathrm{p}=0.54\right)$.

Multiple substrates of attack where prey was captured were used (Fig. 1). Ramphotrigon megacephalum captured their prey mostly on bamboo leaves (76.1\%), followed by bamboo branches (19.4\%). The substrates of attack most used by $R$. fuscicauda were also bamboo leaves (57.7\%), followed by leaves of trees and bushes $(23.7 \%)\left(\chi^{2}=41.185, \mathrm{gl}=7, \mathrm{p}<0.05\right)$.

The food items were usually smaller than the 'bill of the two species of birds. Ramphotrigon megacephalum captured small prey in $93.6 \%$ of the time and $R$. fuscicauda in $85.6 \%\left(\chi^{2}=3.714\right.$, $\mathrm{df}=2, \mathrm{p}=0,15)$. Whenever possible, the prey was identified. The following groups were observed: Lepidoptera (R. megacephalum, $\mathrm{n}$ $=3$ and $R$. fuscicauda, $\mathrm{n}=1$ ), Lepidoptera larvae ( . megacephalum, $\mathrm{n}=5$ and $R$. fuscicauda, $\mathrm{n}=1$ ), Coleoptera ( $R$. fuscicauda, $\mathrm{n}=1$ ) and Orthoptera ( $R$. megacephalum, $\mathrm{n}=2$ ). Several food-handling behaviors were observed. When it was not possible to observe the bird's handling behavior, it was considered as "other". The most observed food-handling behavior in $R$. megacephalum was gulp (63.9\%), followed by "other" (32.1\%). In R. fuscicauda, the most observed behavior was "other" (47.4\%), followed by gulp (35\%) $\left(\chi^{2}=18.270, \mathrm{df}=8, \mathrm{p}<0.05\right)$. The most commonly observed post-attack behavior was the switch to a new perch, for both $R$. megacephalum (70.6\%) and $R$. fuscicauda (49.5\%). In $26.6 \%$ of $R$. megacephalum and $43.3 \%$ of $R$. fuscicauda observations, birds were not located again, making it impossible to see food handling and post-attack behavior $\left(\chi^{2}=10.043, \mathrm{gl}=2, \mathrm{p}\right.$ $<0.05)$. The Student's t-test results for continuous variables of foraging behavior are shown in Table 1 .

\section{DISCUSSION}

Except for the substrate of attack, the foraging techniques used by the two species are very similar. The behavior of following mixed flocks has been described for R. megacephalum but it is rare in R. fuscicauda (PArker 1984, Schulenberg et al. 2007). The findings of this study support those previous observations.

In the present study, the search substrates most widely used by both species during foraging were culms and secondary branches of bamboo - not unexpected in areas dominated by bamboo where other kinds of perches are scarce (SILVEIRA 2005).

Ramphotrigon megacephalum performs short upward strikes, capturing insects on bamboo leaves or branches, occasionally capturing flying insects in the air, whereas $R$. fuscicauda makes short forward and upward strikes, capturing insects on foliage and branches (PARKER 1984). Observations made in the present study also corroborate PARKER (1984). A behavior study involving 28 flycatcher species also considered the sally-strike attack movement as the most common amongst the studied species (Gabriel \& Pizo 2005). Out of the 23 R. fuscicauda foraging events, $65 \%$ were upward strikes, 17\% downward strikes and $13 \%$ upward hovering (FITZPATRICK et al. 2004), similar results to the ones found in this study.

For both species, the most observed attack direction was diagonal-up and, to a lesser extent, diagonal-down. The attack direction most frequently used varies according to the species (Gabriel \& Pizo 2005). Although downward flights spend less energy than an upward flight (against gravity) (MARTINS-OLIVEIRA et al. 2012), upward flights are common in several flycatcher species (Fitzpatrick 1980, 1981, Gabriel \& Pizo 2005). In the case of species that capture their prey on vegetation, the upward flight is advantageous because most insects can be found on the inferior part of the foliar limb, where they seek refuge against predators and protection from sunlight (PARRINI 2015). During the evolution of forestry flycatchers, species adjusted their foraging techniques in order to optimize prey capture, and the greater occurrence of upward flights may be explained by the increased availability of prey (PARRINI 2015).

The attack substrate mostly used by both species was bamboo leaves, which is the most abundant substrate in forests dominated by bamboos. The second substrate on which $R$. megacephalum captured their prey was bamboo branches. Those secondary branches sprout from bamboo culms and, as the leaves, harbor a number of insects. Most prey captured by both

Table 1. Result of the Student's t test for continuous variables of the foraging behavior of Ramphotrigon megacephalum and $R$. fuscicauda.

\begin{tabular}{lccc}
\hline \multicolumn{1}{c}{ Variables } & R. megacephalum & R. fuscicauda & Student's t test \\
\hline Foraging height $(\mathrm{m})$ & $5.85 \pm 1.56 \mathrm{~m}(\mathrm{n}=144)$ & $4.64 \pm 2.19 \mathrm{~m}(\mathrm{n}=164)$ & $\mathrm{t}=-5.5696, \mathrm{p}<0.05$ \\
Search time $(\mathrm{s})$ & $116.22 \pm 98.46 \mathrm{~s}(\mathrm{n}=97)$ & $100.67 \pm 95.14 \mathrm{~s}(\mathrm{n}=109)$ & $\mathrm{t}=-1.1495, ; \mathrm{p}=0.25$ \\
Distance covered on attack $(\mathrm{m})$ & $0.71 \pm 0.43 \mathrm{~m}(\mathrm{n}=97)$ & $0.90 \pm 0.62 \mathrm{~m}(\mathrm{n}=109)$ & $\mathrm{t}=-2.5485, \mathrm{p}<0.05$ \\
Number of perches & $3.43 \pm 2.43(\mathrm{n}=97)$ & $2.23 \pm 1.65(\mathrm{n}=109)$ & $\mathrm{t}=-4.1526, \mathrm{p}<0.05$ \\
Search time by perch $(\mathrm{s})$ & $37.72 \pm 24.68 \mathrm{~s}(\mathrm{n}=97)$ & $44.90 \pm 33.68 \mathrm{~s}(\mathrm{n}=109)$ & $\mathrm{t}=1.7267, \mathrm{p}=0.08$ \\
\hline
\end{tabular}


species were small in relation to the bird's bill. When prey items are small, birds swallow them quickly, without any additional manipulation, which would require greater energy expenditure (REMSEN \& RoBinson 1990).

Species of Ramphotrigon usually remain perched and still for long periods of time (PARKER 1984). Larger flycatcher species move less during foraging (DeLgadillo 2011). During foraging, birds are classified according to the number of perch changes by minute, with the slow searcher being the one with less than 10 perch changes per minute; the intermediate searcher with 14 to 16 perch changes per minute; and the fast searcher with over 24 perch changes per minute (RoBISON \& Holmes 1982). According to this classification, both species studied are considered slow searchers.

Flycatcher species that capture their prey on vegetation are defined as sally-gleaners and usually perch near the substrates where they find their prey (FITZPATRICK 1980). This short distance possibility optimizes the bird's visual field, increasing its chances to detect a prey. In the present study, both species almost invariably captured their prey in the vegetation; hence, birds search for prey close to the substrate of attack and therefore, make shorter flights.

According to SHERRY (1979), species of the same ecological guild may differ in some respects when occupying the same places, even if they have similar morphology and foraging behavior. The presence of aggressive interactions, mediated by subtle habitat preferences, lead to a dominance relationship between species. Usually the dominated species are smaller, more generalist and defend larger territories. Relative dominance and niche breadth play an important role in the coexistence of species in same ecological guild (SHERry 1979). The estimated size of the territory for $R$. fuscicauda is greater than of $R$. megacephalum (16.4 and 4.6 ha, respectively) (LebBin 2013). This, added to the fact that $R$. fuscicauda is not as specialized in bamboos as $R$. megacephalum, may be related to a dominance relationship between these species. In this context, $R$. fuscicauda should be the subordinated species; although its larger size does not correspond to the proposed by SHERRY (1979), which states that the subordinate species is smaller.

Three other aspects help to explain the coexistence of these species: the abundance of insects in bamboo forests; prey differences; and habitat preferences. Studies demonstrate that the dense habitat provided by bamboo culms and leaves support a rich community of arthropods, which represent an abundance of food for insectivorous birds (JANZEN 1976, ReID et al. 2004) and explain the large number and density of insectivorous bamboo specialists (Kratter 1997, Cockle \& Areta 2013). The dense bamboo leaf cover may promote this ecological guild of flycatchers that capture prey on vegetation. As in Ramphotrigon, this abundance of resources probably enables the coexistence between these species, minimizing competition.

Both species have small differences in total length and bill size. Ramphotrigon fuscicauda is larger (15.5 to $16.5 \mathrm{~cm}$ ) than R. megacephalum (12.5 to $13.2 \mathrm{~cm}$ ) (Fitzpatrick et al. 2004). The bill of ( $R$. fucicauda is $15.3 \mathrm{~mm} \pm 1.3 ; \mathrm{n}=6$ and the bill of $R$. megacephalum (is $13.6 \pm 0.7 \mathrm{~mm} ; \mathrm{n}=6$ ). Although the difference is small, it may be related to a difference in the size or type of prey. A difference in foraging sites between the two species was observed and, although it has not been quantified, it may be an important factor for their coexistence. Ramphotrigon fuscicauda generally forages in sites with higher density of bamboo culms and leaves, compared with R. megacephalum. According to SHERRY (1979), species that share the same area can be separated horizontally by different habitat preferences.

Our study demonstrates that the niche breadths of $R$. fuscicauda and $R$. megacephalum are different. Except for one foraging event, $R$. megacephalum used only bamboo substrates, unlike $R$. fuscicauda, which is more generalist. This result helps to explain why $R$. megacephalum bolivianum seems to be restricted to bamboo forests across its range, while $R$. fuscicauda occurs in other habitats, such as lowland forests, which have a high density of vines and a structure similar to bamboo forests. Like other flycatchers, the foraging behavior of these species is stereotyped and the differences, although subtle, explain the coexistence between them.

\section{ACKNOWLEDGMENTS}

The authors thank the PPBio team in Acre for their logistical support; the coordination of the Master's Program in Ecology and Natural Resources Management from UFAC, Macaxeira (in memoriam) for helping with fieldwork, Caio Graco, Francisco Mallet, Elder Morato and Carlos Gussoni for reviews and suggestions on a previous version of this manuscript. We also thank Sidnei M. Dantas, who kindly provided the bill measurements of the specimens in the MPEG collection, Ana Carolina Antunes for reviewing the English of a previous version of this manuscript, and CAPES for the scholarship given.

\section{LITERATURE CITED}

Barroso JG, Salimon CI, Silveira M, Morato EF (2011) Influência de fatores ambientais sobre a ocorrência e distribuição espacial de cinco espécies madeireiras exploradas no Estado do Acre, Brasil. Scientia Forestalis 39: 489-499.

Carvalho Al, Nelson BW, Bianchini MC, Plagnol D, Kuplich TM, DALY DC (2013) Bamboo-dominated forest of the southwest Amazon: detection, spatial extent, life cycle length and flowering waves. Plos One 8: 1-13. doi: 10.1371/jornal.pone.0054852

Cockle KL, Areta JI (2013) Specialization on bamboo by neotropical birds. The Condor 115: 217-220. doi: 10.1525/ cond.2013.120067

Delgadillo EB (2011) Cuantificando el comportamiento: estratégias de búsqueda y ecologia de forrageo de 12 especies sintópicas de Atrapamoscas (Tyrannidae) en La Sierra Nevada de Santa Marta, Colombia. Revista Brasileira de Ornitologia 19: 343-357. 
FitZPATRICK JW (1980) Foraging behavior of neotropical tyrant flycatchers. The Condor 82: 43-57.

FitZPATRICK JW (1981). Search strategies of tyrant flycatchers. Animal Behaviour 29: 810-821.

Fitzpatrick JW, Bates JM, Bostwick KS, Caballero IC, Clock BM, Farnsworth A, IIosner PA, Joseph L, Langham GM, Lebbin DJ, Mobley JA, Robbins MB, Scholes E, Tello JG, Walther BA, Zimmer KJ (2004) Family Tyrannidae (tyrant-flycatchers), p. 170-462. In: Del Hoyo J, Elliott A, Christie DA (Eds.) Handbook of the birds of the world. Barcelona, Lynx Editions, vol. 10, 895p.

Gabriel VA, Pizo MA (2005) Foraging behavior of tyrant flycatchers (Aves, Tyrannidae) in Brazil. Revista Brasileira de Zoologia 22: 1072-1077. doi: 10.1590/s0101-81752005000400036

Guilherme E, Santos MPD (2009) Birds associated with bamboo forests in eastern Acre, Brazil. Bulletin of the British Ornithological Club 129: 229-240.

JANZEN DH (1976) Why bamboos wait so long to flower. Annual Review of Ecology and Systematics 7: 347-391.

Kratter AW (1997) Bamboo specialization by amazonian birds. Biotropica 29: 100-110. doi: 10.1525/cond.2013.120067

Lebirn DJ (2013) Nestedness and patch size of bamboo-specialist bird communities in southeastern Peru. The Condor 115: 230-236. doi: 10.1525/cond.2013.110092

Lopes LE (2005) Dieta e comportamento de forrageamento de Suiriri affinis e $S$. islerorum (Aves, Tyrannidae) em um fragmento de cerrado do Brasil central. Iheringia, Série Zoologia, 95: 341-345. doi: 10.1590/s0073-47212005000400001

Martins-Oliveira L, Leal-Marques R, Nunes CH, Franchin AG, MARÇAL JunIOR O (2012) Forrageamento de Pitangus sulphuratus e de Tyrannus melancholicus (Aves: Tyrannidae) em habitats urbanos. Bioscience Journal 28: 1038-1050.

PARKer III TA (1984) Notes on the behavior of Ramphotrigon Flycatchers. Auk 101: 186-188.

PARRINI R (2015) Quatro estações - História natural das aves da Mata Atlântica: uma abordagem trófica. Rio de Janeiro, Technical Books Editora, 354p.

R Core Team (2014) R. Version 3.3.1. Available online at: https:// www.r-project.org [Accessed: 14/07/2014]

Rasmussen DT, Rehg JA, Guilherme E (2005) Avifauna da Fazenda Experimental Catuaba: uma pequena reserva florestal no leste do Estado do Acre, Brasil, p. 173-198. In: DRumond PM (Org.). Fauna do Acre. Rio Branco, Edufac.
Reid S, Diaz IA, Armesto JJ, Willson MF (2004) Importance of native bamboo for understory birds in Chilean temperate forests. Auk 121: 515-525.

REMSEn JV, Robinson SK (1990) A classification scheme for foraging behavior of birds in terrestrial habitats, p. 144-160. In: MorRISON ML, RALPH CJ, VERnER J, JEHL JR JR (Eds.) Avian foraging: theory, methodology, and applications. Lawrence, Cooper Ornithological Society, Studies in Avian Biology 13, 515p.

RoBINSON SK, Holmes RT (1982) Foraging behaviorof forest birds: the relationships among search tactics, and habitat structure. Ecology 63: 1918-1931.

SChaEfer CEGR (2013) Clima e paleoclima do Acre: memórias e cenários da aridez quaternária na Amazônia e implicações pedológicas, p. 59-79. In: Anjos LHC, SiLva LM, WADT PGS, Lumbreras JF, Pereira MG (Eds.) Guia de campo da IX reunião brasileira de classificação de classificação e correlação de solos. Brasilia, Embrapa, 204p.

Schulenberg TS, Stotz DF, Lane DF, O’Neill JP, Parker III TA (2007) Birds of Peru. New Jersey, Princeton University, 664p.

SHERry TW (1979) Competitive interactions and adaptative strategies of American Redstarts and Least Flycatchers in a northern hardwoods forest. Auk 96: 265-283.

Silveira M (2005) A floresta aberta com bambu no sudoeste da Amazônia: padrões e processos em múltiplas escalas. Rio Branco, Edufac, 152p.

Systat (2008) Systat. San Jose, California, Systat Sofware Inc., v. 12.0 .

Submitted: 7 June 2016

Received in revised form: 11 September 2016

Accepted: 25 September 2016

Editorial responsibility: Luís Fábio Silveira

Author Contributions: TNM conducted the fieldwork, analyzed the data and wrote the paper. EG provided logistical support; guided and reviewed the research project and the first version of the paper.

Competing Interests: The authors have declared that no competing interests exist. 